\title{
Intercomparison of FLEXPART and CALPUFF dispersion models. An application over a small tropical island
}

\author{
Anel HERNÁNDEZ-GARCÉS ${ }^{1 *}$, Raphaël CÉCÉ ${ }^{2}$, Adrian Luis FERRER-HERNÁNDEZ ${ }^{3}$, \\ Didier BERNARD ${ }^{2}$, Ulises JÁUREGUI-HAZA ${ }^{4}$, Narcisse ZAHIBO ${ }^{2}$ and José A. GONZÁLEZ ${ }^{5}$ \\ ${ }^{1}$ Facultad de Ingeniería Química, Universidad Tecnológica de La Habana “José Antonio Echeverría”, La Habana, \\ Cuba. \\ ${ }^{2}$ Laboratory for Research in Geosciences and Energy (LaRGE), Department of Physics, University of the French West \\ Indies, Pointe-à-Pitre, Guadeloupe. \\ ${ }^{3}$ Instituto de Meteorología de la República de Cuba (INSMET), La Habana, Cuba. \\ ${ }^{4}$ Instituto Tecnológico de Santo Domingo (INTEC), Santo Domingo, República Dominicana. \\ ${ }^{5}$ Centro Interdisciplinar de Investigación en Tecnologías Ambientales (CRETUS), Departamento de Ingeniería Química, \\ Universidad de Santiago de Compostela, Galicia, España. \\ *Corresponding author; e-mail: anel@quimica.cujae.edu.cu
}

Received: January 10, 2020; accepted: June 10, 2020

\begin{abstract}
RESUMEN
La intercomparación entre resultados de diferentes modelos de dispersión y mediciones de la calidad del aire en condiciones atmosféricas diferentes es una práctica común en la evaluación de dichos modelos. En este estudio se realiza una comparación de resultados de dos modelos de dispersión: el modelo lagrangiano de dispersión de partículas FLEXPART y el modelo lagrangiano de puffs ("bocanadas") CALPUFF (modelo regulatorio), acoplados a los mismos campos meteorológicos producidos por el Modelo de Investigación y Pronóstico Meteorológico (WRF, por sus siglas en inglés). Como caso de estudio se consideró la dispersión atmosférica de emisiones antrópicas de óxidos de nitrógeno $\left(\mathrm{NO}_{\mathrm{x}}\right)$ (consideradas como un trazador pasivo) durante un caso típico de contaminación severa sobre un área densamente poblada del archipiélago de Guadalupe (Antillas Francesas Occidentales). Se tomaron en cuenta los efectos del terreno complejo y, por supuesto, la influencia costera. Aunque los modelos lagrangianos generalmente brindan mejores resultados de dispersión de la pluma con vientos fuertes, este estudio de caso se realizó en condiciones de vientos alisios débiles dominantes, con el fin de verificar ambos modelos en condiciones atmosféricas no ideales. Como resultado, en comparación con mediciones de concentración de $\mathrm{NO}_{\mathrm{x}}$ en superficie, FLEXPART muestra una mejor concordancia que CALPUFF. Sin embargo, como modelo regulatorio, CALPUFF sobreestima tanto las concentraciones en superficie como el máximo de FLEXPART, con valores más altos cuando se aplica una resolución horizontal más elevada. Además, se observan diferencias entre los resultados de los modelos en la distribución espacial de $\mathrm{NO}_{\mathrm{x}}$ en el dominio de resolución horizontal de $1 \times 1 \mathrm{~km}^{2}$, los cuales muestran isolíneas bastante homogéneas con contornos suaves para CALPUFF frente a isolíneas fragmentadas con contornos irregulares para FLEXPART.
\end{abstract}

\section{ABSTRACT}

A typical practice in air quality modeling assessment is the intercomparison between different dispersion models results and air quality measurements at different atmospheric conditions. In this study, a comparison between the results of two Lagrangian dispersion models, the Lagrangian Particle Dispersion Model FLEXPART and the Lagrangian Puff Model CALPUFF (regulatory model), coupled to the same meteorological fields produced by the Weather Research and Forecasting (WRF) model, was done. As a case study, atmospheric dispersion of anthropogenic nitrogen oxides $\left(\mathrm{NO}_{\mathrm{x}}\right)$ emissions (considered as a passive tracer) was considered, during a typical case of severe pollution over the densely populated area of the Guadeloupe archipelago (West French Indies), including complex terrain and, of course, coastal influence. Even though Lagrangian models usually provide better results of plume dispersion under strong winds, in this case study weak trade winds are dominant, in order to check both models under non-ideal atmospheric conditions. As a result, compared to $\mathrm{NO}_{\mathrm{x}}$ ground level 
concentration (glc) observations, FLEXPART shows better agreement than CALPUFF. However, as a regulatory model, CALPUFF overestimates both glc observations and FLEXPART maximum $\mathrm{NO}_{\mathrm{x}}$ glc results, with higher values when a higher horizontal resolution is applied. Also, differences between models results arise in the spatial distribution of $\mathrm{NO}_{\mathrm{x}}$ over a $1 \times 1 \mathrm{~km}^{2}$ horizontal resolution grid domain, showing quite homogenous isopleths with smooth contours for CALPUFF vs. fragmented isopleths with irregular contours for FLEXPART.

Keywords: FLEXPART, CALPUFF, atmospheric dispersion modeling, tropical island.

\section{Introduction}

Air quality modeling is an essential tool for most air pollution studies (Seinfeld and Pandis, 2012). In that sense, Lagrangian models provide an effective method for simulating atmospheric diffusion when chemical reactions are not relevant. Specifically, Lagrangian models can estimate the local air pollution produced by emissions from a large power plant (Souto et al., 2000). They have usually been accepted as the most adequate models for estimating the local plume dispersion from single large point sources (Souto et al., 2009). Currently, the Lagrangian modeling approach is mainly divided into two different categories: particle models and puff models (Zannetti, 2013). In this work, a comparison between two representative Lagrangian models, FLEXPART and CALPUFF, coupled to the WRF meteorological model (Skamarock et al., 2008) is performed.

FLEXPART (Stohl et al., 1998) is a widely used Lagrangian particle model that simulates the transport and dispersion of tracers by calculating the trajectories of a multitude of particles. As in some of the most recent FLEXPART model studies at different regions all over the world, Wei et al. (2011) used models coupling (WRF-FLEXPART) to describe the impact of high-pressure conditions on the air quality in northern China. Using the same model coupling, Bei et al. (2013) analyzed meteorological conditions and plume transport patterns during the Cal-Mex 2010 study in Tijuana, Mexico. Halse et al. (2013) developed a forecasting system based on FLEXPART for long-term forecast and assessment of polychlorinated biphenyls atmospheric transport in different observed air pollution episodes at remote sites in southern Norway. Also, Arnold et al. (2015) investigated the role of precipitation in the Fukushima nuclear accident (Tanaka, 2012; Yang, 2014). Besides, Djambazov and Pericleous (2015) applied the FLEXPART model to estimate how N air pollutant emissions contribute to the sea solved nitrogen in the English Channel and the south of the North Sea. Miao et al. (2015) studied the transport mechanisms of pollutants during a fog event at Bohai Bay, China, using WRF-FLEXPART models coupling to understand the effects of local atmospheric circulation and atmospheric boundary layer structure in the air pollution levels. Then, Srinivas et al. (2016) examined the sensitivity of FLEXPART to the meteorological data inputs simulated by the mesoscale model ARW in the Kalpakkam coastal environment. Newly, Cheng et al. (2017) simulated a total monthly $\mathrm{CO}_{2}$ footprint using FLEXPART.

In these studies, FLEXPART has usually been applied to long distance air pollution transport, with strong circulation patterns providing quite straight trajectories. However, FLEXPART can also be applied at a local scale in weak wind conditions. As an example, Cécé et al. (2016) modeled the dispersion of anthropogenic nitrogen oxides $\left(\mathrm{NO}_{\mathrm{x}}\right)$ emissions over the densely populated area of the Guadeloupe archipelago under weak trade winds during a typical case of severe pollution.

CALPUFF (Scire et al., 2000) is one of the most versatile and most applied Lagrangian puff models used in recent years (Hernández-Garcés et al., 2016). It is a multi-layer, multi-species non-steady-state puff dispersion model that can simulate the effects of time- and space-varying meteorological conditions on pollutant transport, transformation, and removal. CALPUFF contains algorithms for near-source effects such as building downwash, transitional plume rise, partial plume penetration, sub-grid scale terrain interactions as well as longer range effects such as pollutants removal (wet scavenging and dry deposition), chemical transformation, vertical wind shear, overwater transport and coastal interaction effects. Also, a regulatory version of the CALPUFF model is available, which tries to guarantee that model results are mainly higher than the observed air pollution levels. 
As CALPUFF is a very flexible Lagrangian puff model with different solutions of atmospheric dispersion phenomena, different validation tests of the CALPUFF model have been published (O'Neill et al., 2001; Levy et al., 2003; Protonotariou et al., 2004; Cohen et al., 2005; Yau and Macdonald, 2010; Dresser and Huzier, 2011; Fishwick and Scorgie, 2011; Ghannam and El-Fadel, 2013). As some of the most recent CALPUFF studies, Rood (2014) validated CALPUFF in an industrial zone in Denver, Colorado, USA. Hernández-Garcés et al. (2015a) performed different CALPUFF assessments by simulating the local dispersion of $\mathrm{SO}_{2}$ (as a passive tracer) from a large power plant smokestack (356.5 $\mathrm{m}$ height, with four parallel independent pipes inside the same concrete structure), considering both different stack modeling settings (four pipers vs. one equivalent single pipe) and meteorological inputs (both meteorological models results and observations). Pivato et al. (2015) applied CALPUFF to assess the airborne concentration of an emitted pesticide. Holnicki et al. (2016) presented a case study application of the CALPUFF model at an urban scale over the Warsaw area. More recently, Fallah-Shorshani et al. (2017) simulated the pollutants transport at the top of the urban canopy using CALPUFF as part of an integrated modeling system to simulate ambient nitrogen dioxide in a dense urban neighborhood.

Apart from the mesoscale wind provided as input to any Lagrangian model, two main phenomena affect these model's performance at the local scale: the atmospheric turbulence, as pollutant atmospheric diffusion depends on it; and the planetary boundary layer (PBL) depth, because pollutants plume rise is usually limited by this depth.

About the atmospheric turbulence effect, both FLEXPART and CALPUFF models follow the classical Lagrangian approach of increasing the element (either puff or particle) position every time step $\Delta t$ by adding a $v \Delta t$ distance. However, in the case of the FLEXPART particle model, $v$ includes not only the mesoscale wind speed but also the turbulent wind fluctuations effect, in order to estimate the pollutants' atmospheric diffusion; this FLEXPART approach is based on the parameterization scheme for statistical models proposed by Hanna (1982) and modified by Ryall and Maryon (1997). On the other hand, CALPUFF represents atmospheric diffusion using a piece-wise Gaussian distribution, as in previous adaptive puff models (Ludwig et al., 1989; Souto et al., 1998). Although CALPUFF provides several options to estimate atmospheric Gaussian diffusion parameters, the classical approach, based on the similarity theory (Monin and Obukhov, 1954), was adopted.

About PBL depth, the applied estimation with both models is based on the bulk Richardson approach of Vogelezang and Holtslag (1996) with different convective velocity scale, $w^{*}$.

CALPUFF coupled to WRF meteorological model (Skamarock et al., 2008) derives this friction velocity from the vertical eddy fluxes of momentum WRF results $\left(\left|w^{\prime} u^{\prime}\right|\right)$, using the Mesoscale Model Interface (MMIF) meteorological preprocessor (Brashers and Emery, 2016) that applies the Deardorff (1970) expression

$$
\mathrm{W} *=\sqrt[3]{\frac{\left(\mathrm{w}^{\prime} \Theta^{\prime}{ }_{\mathrm{v}}\right)}{\mathrm{T}_{\mathrm{v}}} \mathrm{gz}_{\mathrm{i}}}
$$

where $g$ is the gravitational acceleration, $T_{\mathrm{v}}$ is the absolute temperature, $z_{\mathrm{i}}$ is the average depth of the mixed layer, and $\overline{\left(w^{\prime} \Theta^{\prime}{ }_{v}\right)_{0}}$ is the kinematic vertical turbulent flux of virtual potential temperature near the surface (Stull, 1988).

On the other hand, FLEXPART follows the convective velocity scale suggested by Vogelezang and Holtslag (1996):

$\mathrm{W}_{*}=\sqrt[3]{\frac{\left(\mathrm{w}^{\prime} \Theta^{\prime}{ }_{\mathrm{v}}\right)_{0}}{\Theta^{\prime}{ }^{\prime} h_{\text {mix }}}}$

where $\overline{\left(w^{\prime} \Theta^{\prime}{ }_{v}\right)_{0}}$ is the heat flux, $g$ is the acceleration due to gravity, $h_{\text {mix }}$ is the PBL height, and $\Theta^{\prime}{ }_{v 1}$ is the improved temperature scale at the $1^{\text {st }}$ model level (Holtslag and Nieuwstadt, 1986).

Both $w^{*}$ formulations are analogous, thus similar PBL depth estimations are expected for simulations obtained with CALPUFF and FLEXPART. However, MMIF also incorporates the methodology of Gryning and Batchvarova (2003), which reduces the critical Richardson number for overwater PBL heights from 0.25 to 0.05 . Therefore, in a small island domain, it is expected that overwater MMIF PBL depth will be smaller than the FLEXPART PBL depth estimation.

This is just one example of the influence of the simulation domain conditions in model assessment and intercomparison. Therefore, it is common to 
compare models results at different conditions. Different CALPUFF and AERMOD regulatory model comparisons were published (Dresser et al., 2011; Tartakovsky et al., 2013, 2016; Gulia et al., 2015). Also, Scire et al. (2013) added a comparison with CAMx (Tesche et al., 2001) using its plume-in-grid approach. Rood (2014) performed a comparison between the former regulatory model Industrial Source Complex 2 (US-EPA, 1992) and RATCHET (Ramsdell et al., 1994). Other researchers compared CALPUFF with different models: Yau et al. (2010) against AUSTAL2000 (VDI, 2000); Protonotariou et al. (2004) against Eulerian models UAM (Causley, 1992) and REMSAD (ICF Consulting, 2002); Chang et al. (2003) against HPAC (DTRA, 1999) and VLSTRACK (Bauer and Gibbs, 1998).

Also, some FLEXPART model comparisons were performed at long distance experiments. Probably the most comprehensive is the comparison against HYSPLIT (Draxler and Hess, 1998), CALPUFF and other two dispersion models in the European Tracer Experiment (ETEX) and the Cross-Appalachian Tracer Experiment (CAPTEX), using a tracer cloud dispersion. This last study concluded that CALPUFF performance was significantly poorer than the performance of the other three models in the ETEX experiment, while CALPUFF results were improved in CAPTEX (Anderson and Brode, 2010). At a local scale, Souto et al. (2001) compared two Lagrangian models during an $\mathrm{SO}_{2}$ air pollution episode, the Lagrangian particle model (LPM; Pielke, 1984) and the Adaptive Puff Model 2 (APM2; Souto et al., 1998), concluding that, even though vertical concentration profiles provided by LPM are more heterogeneous than estimated by APM2 (with the same meteorological input), this puff model achieved a better agreement to glc observations than LPM, as APM2 was able to reproduce observed local hotspots that were not estimated by LPM. However, previous studies at different domains indicated that Lagrangian particle models usually provide better results than other simple Gaussian puff models (Saltbones et al., 1996). Therefore, model performance depends not only on the basic modeling approach (i.e., particles vs. puffs) but also on the modeling solutions for specific phenomena (plume rise, building effects, etc.) and on the domain conditions (Hernández-Garcés et al., 2015b).
This is why in this work a singular simulation domain was selected, the Guadeloupe archipelago, including the complexity of small orographic tropical islands (width $<50 \mathrm{~km}$ ) with strong sea influence at the Caribbean region. Particularly, from medium to weak trade winds $\left(<7 \mathrm{~ms}^{-1}\right)$, its complex terrain at the Lesser Antilles may induce thermal and orographic local circulations, which strongly affect the air quality levels (Cécé et al 2014, 2016).

In this study, a comparison of the results of two Lagrangian dispersion models, FLEXPART and CALPUFF, coupled to the same meteorological fields input provided by WRF model (Skamarock et al., 2008) was done, considering $\mathrm{NO}_{\mathrm{x}}$ emissions as a passive tracer over the densely populated area of the Guadeloupe archipelago under weak trade winds, during a typical episode of severe pollution.

\section{Materials and methods}

\subsection{Study location}

The Guadeloupe archipelago is located in the middle of the Lesser Antilles arc at $16.22^{\circ} \mathrm{N}$ and $61.55^{\circ} \mathrm{W}$ (Fig. 1). This archipelago includes two main islands: Basse-Terre, a complex terrain island with a

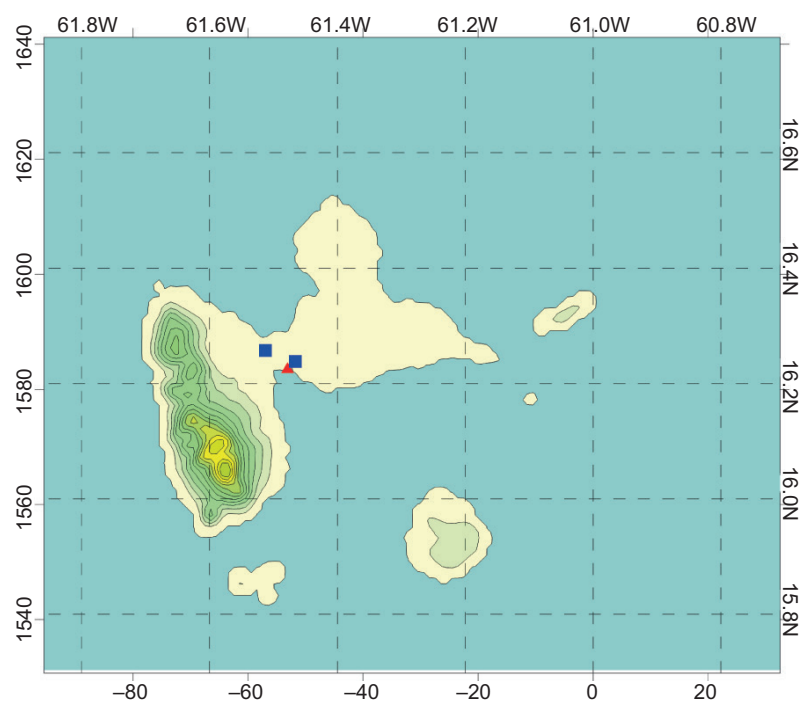

Fig. 1. Map of the Guadeloupe archipelago, with the main $\mathrm{NO}_{\mathrm{x}}$ emission source, a diesel power plant (PWP, red triangle), and two air quality stations near it (blue squares): AQS1 (Pointe-à-Pitre, $1878 \mathrm{~m}$ travel distance) and AQS2 (Baie-Mahault, $6135 \mathrm{~m}$ travel distance). 
maximum elevation height of 1467 masl, and GrandeTerre, a flat terrain island with a maximum elevation height of 135 masl. The archipelago islands form a basin between the two main islands. This region is usually characterized by calm winds, but specific airflows in the atmospheric boundary layer can be observed with strong sea influence along its narrow coastline.

The main anthropogenic sources of atmospheric pollution in this region are a diesel power plant (PWP, Fig. 2) located in the center of the archipelago (Fig. 1) and vehicles on the primary road network. As this is the largest $\mathrm{NO}_{\mathrm{x}}$ emission source in the region, observed $\mathrm{NO}_{\mathrm{x}}$ glc is mainly produced by PWP emissions, so the $\mathrm{NO}_{\mathrm{x}}$ emission can be considered as a tracer of its plume. Two air quality stations near to the PWP (1878 $\mathrm{m}$ and $6135 \mathrm{~m}$ travel distances) are recording data every $15 \mathrm{~min}$, which will be applied in model assessment.

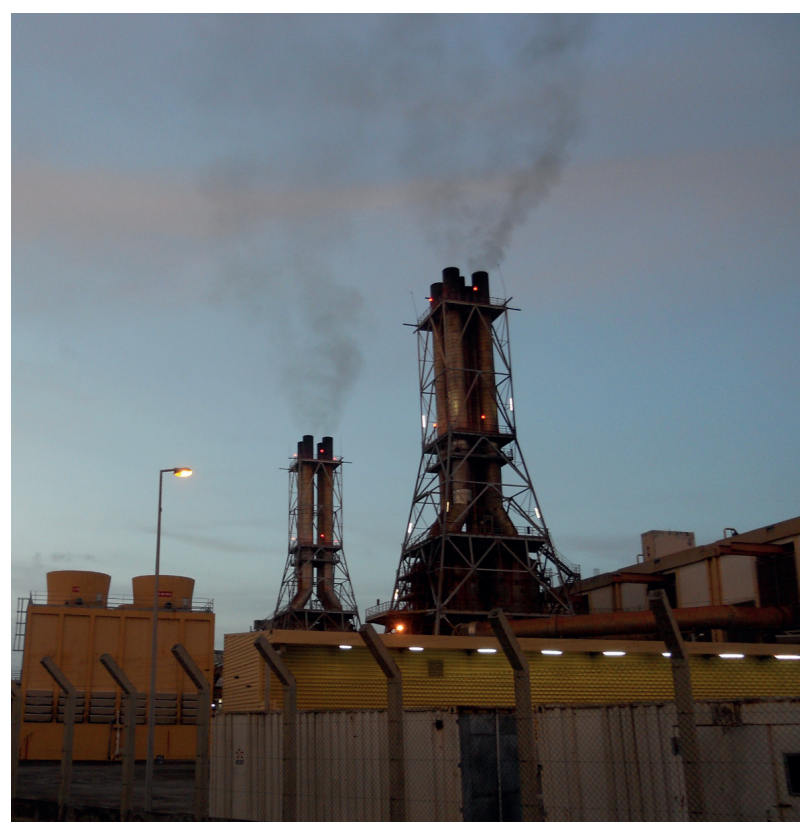

Fig. 2 Diesel power plant located in the center of the Guadeloupe archipelago.

\subsection{Simulation period and WRF meteorological re- sults}

Cécé et al. (2016) studied a period of 24-h (1200 LT December 3-1200 LT December 4, 2007) with high $\mathrm{NO}_{\mathrm{x}}$ glc and weak winds, as the most typical meteorological conditions that produce poor air quality at the two sites available. To evaluate the performance of the two selected Lagrangian models (FLEXPART and CALPUFF) the same period was chosen for model assessment.

Meteorological input for both Lagrangian models was obtained from the WRF model (Skamarock et al., 2008) previously validated simulations (Cécé et al., 2016). Because of the complex terrain and strong sea influence around the domain, six one-way WRF nested grids (Fig. 3) were applied from 27-km horizontal resolution (D1) to 111-m horizontal resolution (D6). However, just the innermost grids WRF results (D4, D5, D6) were applied as meteorological inputs for the air quality simulations.

Taking into account the large differences between the six grids applied, the following WRF model settings were carefully selected to get the best model performance: 70 unequally spaced half vertical eta-levels with the lowest half level at 13 meters above the ground level (magl) and the model top set at $100 \mathrm{hPa}$ pressure level; Rayleigh damping on vertical velocity with a damping layer depth of $5 \mathrm{~km}$; Monin-Obukhov similarity; WRF single-moment 6-class microphysics scheme; Rapid Radiative Transfer Model longwave scheme (Mlawer et al., 1997); the Dudhia shortwave scheme (Dudhia, 1989), and ensemble-mean non-local-K YSU scheme for the PBL in mesoscale domains (Hong et al., 2006).

The topography of the Guadeloupe archipelago (domains D4, D5 and D6) was interpolated from the Institut Géographique National 50-m topographic map and its land-use was interpolated from the $25-\mathrm{m}$ Corine Land Cover map (EEA, 2007) pre-converted to 24 USGS land-use categories (Anderson et al., 1976; Pineda et al., 2004).

As D4 to D6 grids provide the meteorological inputs for air quality simulations, Figure 4 shows the three wind roses obtained from the corresponding grid WRF output at the PWP location. As it is observed in the three domains, changes in wind direction are covering mostly $360^{\circ}$, as in a weak wind condition. However, sea breeze regimes are significant, because some more frequent wind directions are observed, with differences depending on the grid resolution considered: NNE, E and ESE wind directions are the most frequent using D4 (1-km resolution) and D5 (333$\mathrm{m}$ resolution) grids outputs; however, D6 (111-m 

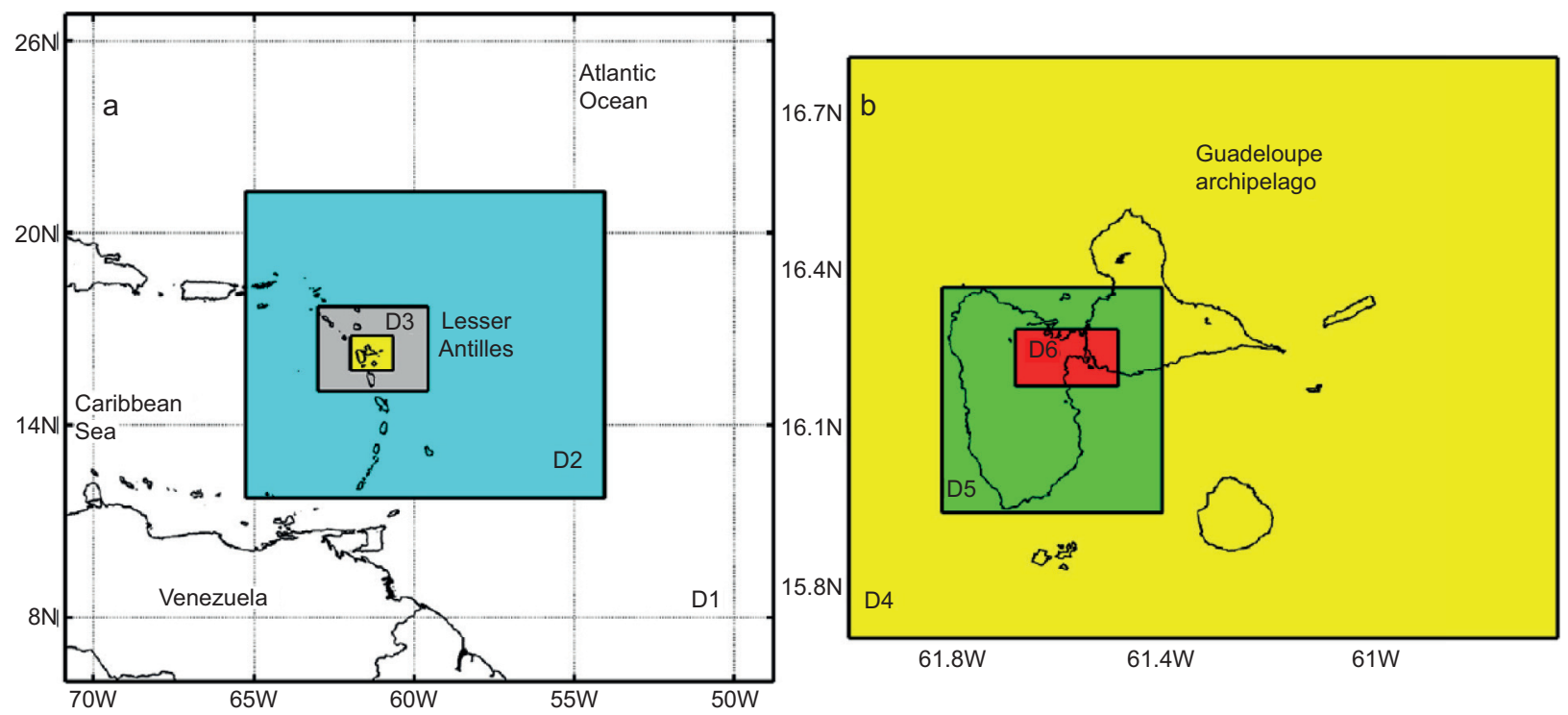

Fig. 3. WRF domain grids resolution: D1: 27 km; D2: 9 km; D3: 3 km; D4: 1 km; D5: 333 m; D6: 111 m (Cécé et al., 2016). D4, D5, D6 grids results provide the meteorological input to FLEXPART and CALPUFF air quality simulations.

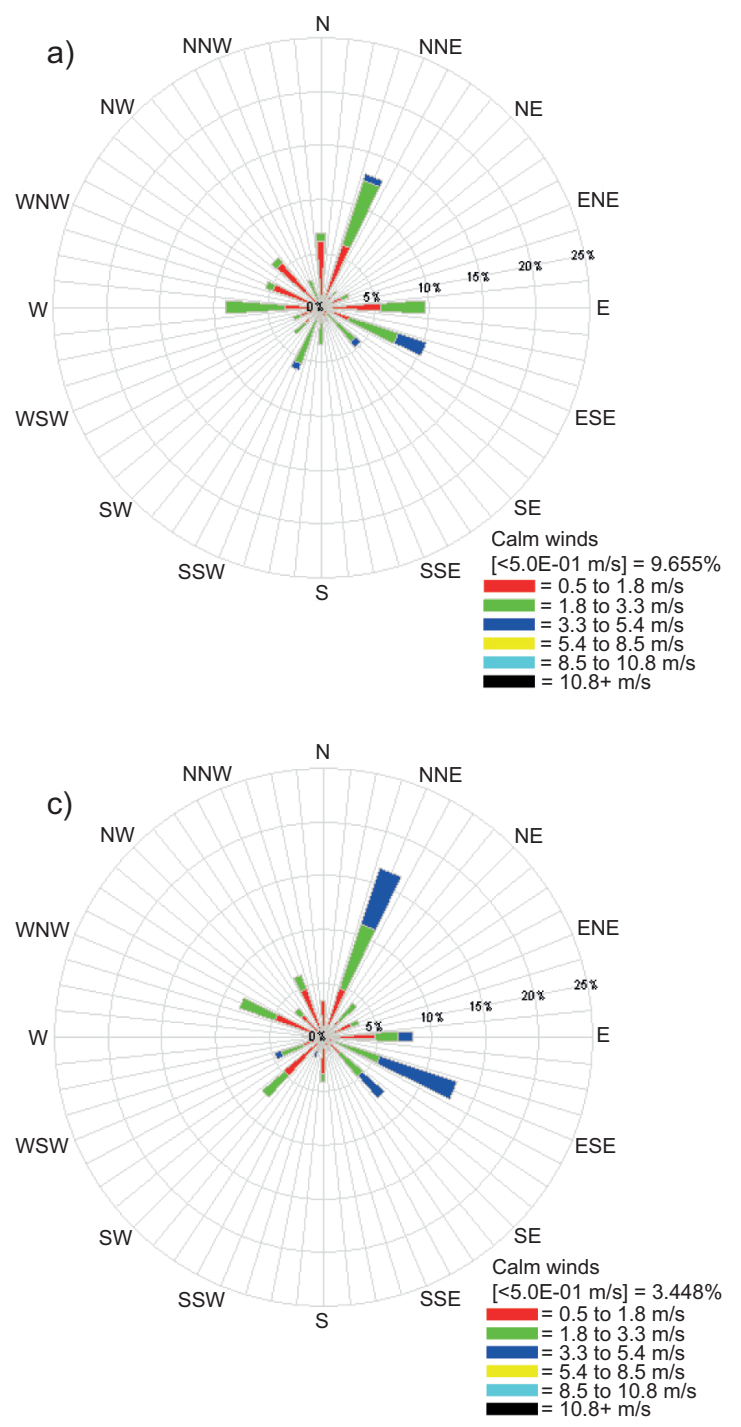

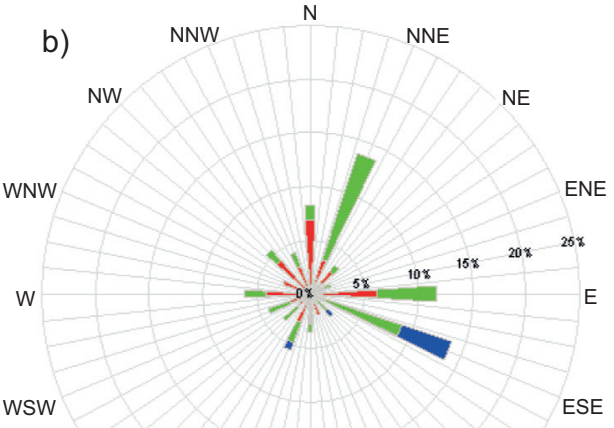

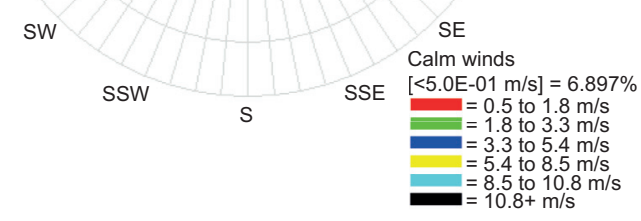

Fig. 4. Comparison between wind roses at the emission source location from each WRF high resolution grid output: (a) D4: $1 \mathrm{~km}$; (b) D5: 333 m; (c) D6: $111 \mathrm{~m}$. 


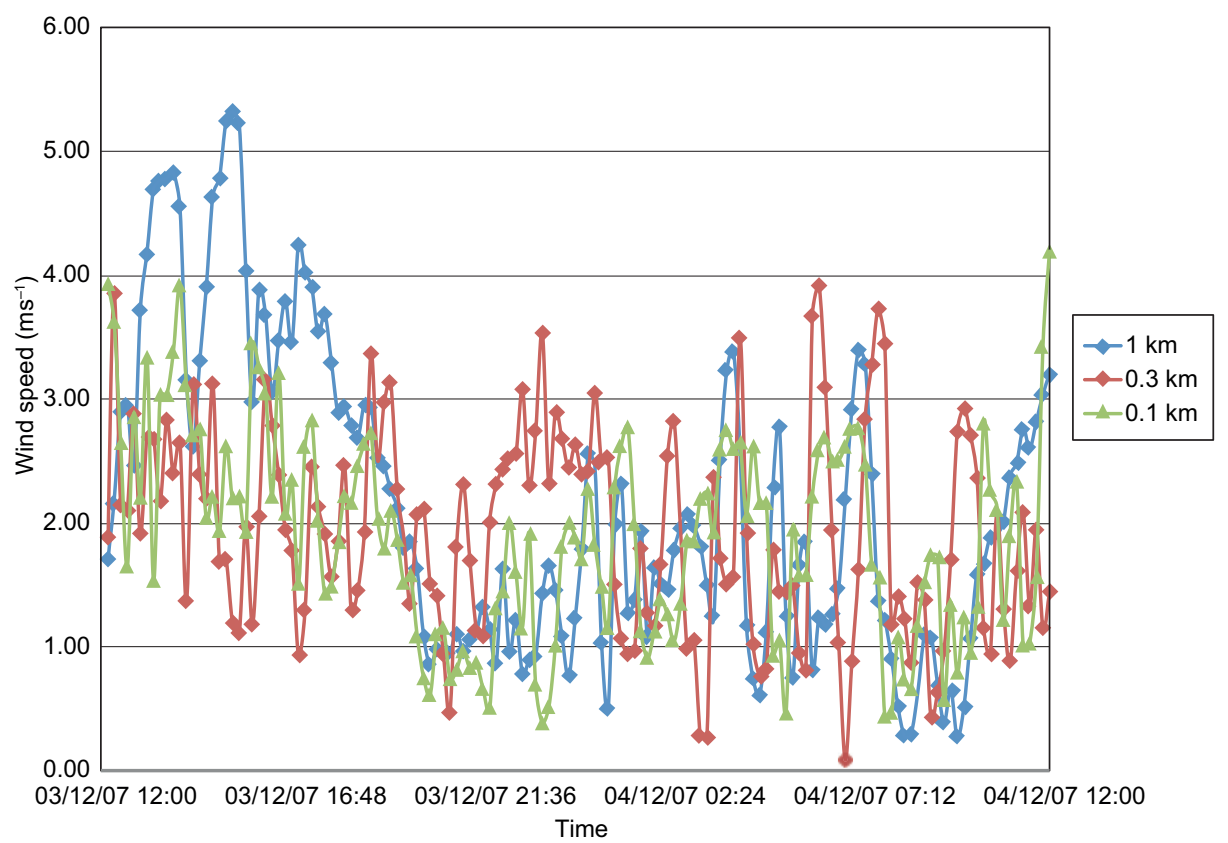

Fig. 5. Wind speed time series at the emission source location from each WRF high resolution grid output: D4: $1 \mathrm{~km}$ (blue diamond line); D5: $333 \mathrm{~m}$ (red diamond line), and D6: $111 \mathrm{~m}$ (green triangles line).

resolution) grid output also shows frequent $\mathrm{W}$ and E wind directions. In addition, wind speed (Fig. 5) is quite different depending on the grid resolution, with frequent values up to $5 \mathrm{~ms}^{-1}$ from D4 output, which are lower from D6 output.

There is more short-term variability in the D5 and D6 wind speeds, especially in the daytime. It is mainly linked with the much finer resolution and the better representation of the lower-levels daytime convection turbulence.

These differences in the WRF meteorological results depending on the grid resolution can be relevant in air quality simulations in this domain. Therefore, the same meteorological input will be set for both Lagrangian models simulations.

\subsection{FLEXPART model setup}

Because of the domain complexity and strong meteorological variability along with the 24 -h simulation, 10-min WRF outputs are provided to the FLEXPART model, following Cécé et al. (2016). These meteorological outputs include mass-weighted time-averaged wind fields, friction velocity, heat sensible flux and PBL height. PBL turbulence is parameterized following the Hanna scheme (Hanna, 1982), which computes turbulent profiles depending on the atmospheric stability of the PBL.

According to the Pollutant Emissions French Register, PWP released 9.79 kt of $\mathrm{NO}_{\mathrm{x}}$ (equivalent $\mathrm{NO}_{2}$ ) in 2007. Based on this annual amount, $\mathrm{NO}_{\mathrm{x}}$ total mass emitted by PWP during $24 \mathrm{~h}$ is set to $26.82 \mathrm{t}$, with a constant emission rate, as no hourly profile information is available. The PWP plume is represented as Cécé et al. (2016) did using plume observational pictures (Fig. 6) by a volume of 30 $\times 30 \times 340 \mathrm{~m}$ centered at $61.5515^{\circ} \mathrm{W}$ and $16.2280^{\circ}$ $\mathrm{N}$. The plume base corresponds with a smokestack height of 60 magl.

In the FLEXPART model, concentrations are calculated on the basis of the number of trajectories located within each grid cell and their mass fraction. The larger the number of released particles, the better represented are the particle mass fraction statistics for each grid cell. Hence, for a given resolution grid, an optimal number of trajectories to run in the model needs to be estimated. In order to determine this number corresponding to result stability, several simulation tests have been made with a number of 

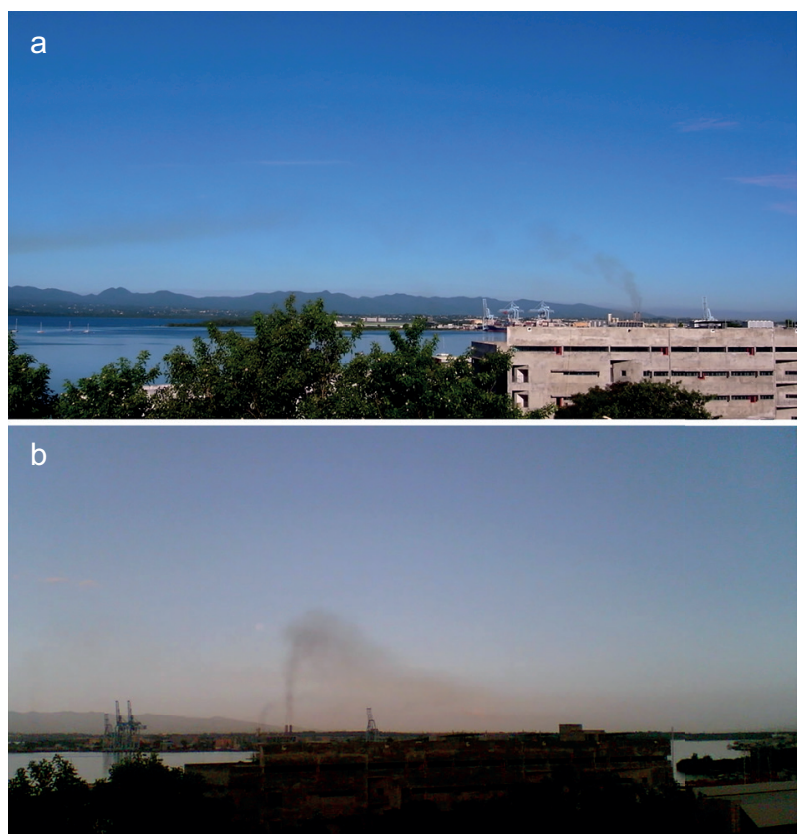

Fig. 6. PWP plume observational pictures: (a) longitudinal section, (b) cross section.

particles released every 15 min ranging from 5000 to 60000 particles. These tests have shown that the result stability was reached for $1-\mathrm{km}, 333-\mathrm{m}$ and 111 -m grids, with the respective number of particles emitted every $15 \mathrm{~min}$ during the 24 -h period: 20000 , 30000 and 50000 (Cécé et al., 2016).

$\mathrm{NO}_{\mathrm{x}}$ dispersion emitted from the PWP is simulated over domains D4, D5 and D6 (simulations: flx $1 \mathrm{~km}$, flx $0.3 \mathrm{~km}$, flx $0.1 \mathrm{~km}$ ). As a result, $\mathrm{NO}_{\mathrm{x}}$ concentrations are computed every $15 \mathrm{~min}$ at the two available air quality stations, AQS1 (Pointe-à-Pitre) and AQS2 (Baie-Mahault). $\mathrm{NO}_{\mathrm{x}}$ concentrations are also computed over a three-dimensional grid, with 38 terrain-following levels (first level at $10 \mathrm{magl}$ and top level at $3000 \mathrm{magl}$ ) and 1, 0.3 and $0.1 \mathrm{~km}$ of horizontal resolution, respectively. However, following PWP plume observational pictures (Cécé et al., 2016), a maximum plume top is set at $400 \mathrm{magl}$.

\subsection{CALPUFF model setup}

The CALPUFF model setting follows default values except for the critical Gaussian dispersion coefficients $\mathrm{s}_{\mathrm{y}}$ and $\mathrm{s}_{\mathrm{z}}$, which are dynamically calculated from $\sigma_{\mathrm{v}}$ and $\sigma_{\mathrm{W}}$ micrometeorological variables values provided by WRF outputs. The PWP emission source representation applied in the FLEXPART model was adapted to the CALPUFF model using the same size. Also, the same WRF meteorological outputs were applied to obtain three different air quality simulations (puff1km, puff0.3km, puff0.1km). However, the MMIF preprocessor (Brashers and Emery, 2016) was required to adapt WRF outputs are CALPUFF meteorological inputs; in this process, new PBL depth values were computed by MMIF with a vertical resolution 20 times the WRF vertical resolution.

Similar to FLEXPART, 37 vertical layers to calculate $\mathrm{NO}_{\mathrm{x}}$ concentrations were set, although with the lowest level at $20 \mathrm{~m}$ because of CALPUFF constraints.

To compare CALPUFF in conditions as close as possible to FLEXPART, a second simplified CALPUFF setting was tested (simulations: puff1kmS, puff0.3kmS, puff0.1 kmS), considering neither the transitional plume rise nor the stack tip downwash, and setting a uniform vertical distribution in the near field; as these local phenomena are not solved by FLEXPART.

Therefore, considering this simplified CALPUFF setting, just two main differences between FLEXPART and CALPUFF settings remain: the lowest vertical level height and the PBL scheme used. Table I summarizes the different configurations applied, classified into two groups.

\subsection{Model assessment and intercomparison}

To obtain a quantitative assessment of FLEXPART and CALPUFF simulations the BOOT statistical model evaluation software package, v. 2.01, as distributed with the model validation kit (Chang and Hanna, 2005) was applied. In this study, the BOOT package was applied to compare 15-min estimated and observed ground level concentrations. Four statistics were considered:

Fractional bias (FB),

$F B=\frac{\left(\bar{C}_{o}-\bar{C}_{p}\right)}{0.5\left(\bar{C}_{o}-\bar{C}_{p}\right)}$

Underpredicting component of the FB (FBFN),

$F B F N=\frac{\frac{1}{2} \sum_{i}\left[\left|C_{o i}-\mathrm{C} c_{p i}\right|+\left(C_{o i}-C_{p i}\right)\right]}{\left.\frac{1}{2} \sum_{i}\left(C_{o i}+C_{p i}\right)\right]}$

Overpredicting component of the FB (FBFP),

$F B F N=\frac{\frac{1}{2} \sum_{i}\left[\left|C_{o i}-C_{p i}\right|+\left(C_{p i}-C_{o i}\right)\right]}{\left.\frac{1}{2} \sum_{i}\left(C_{o i}+C_{p i}\right)\right]}$ 
Table I. Models configuration.

\begin{tabular}{|c|c|c|c|}
\hline Simulations & $\begin{array}{l}\text { WRF grid } \\
\text { resolution input }\end{array}$ & $\begin{array}{l}\text { WRF lowest vertical } \\
\text { level height (magl) }\end{array}$ & PBL scheme \\
\hline \multicolumn{4}{|c|}{ WRF/FLEXPART simulations } \\
\hline $\mathrm{flx} 1 \mathrm{~km}$ & 1-km grid resolution & 10 & \multirow{3}{*}{$\begin{array}{l}\text { Bulk Richardson approach } \\
\text { from Vogelezang and } \\
\text { Holtslag (1996) }\end{array}$} \\
\hline $\mathrm{flx} 0.3 \mathrm{~km}$ & 0.3-km grid resolution & & \\
\hline $\mathrm{flx} 0.1 \mathrm{~km}$ & 0.1-km grid resolution & 38 & \\
\hline \multicolumn{4}{|c|}{ WRF/CALPUFF simulations } \\
\hline Simulations & WRF grid resolution input & $\begin{array}{l}\text { WRF lowest vertical } \\
\text { level height (magl) }\end{array}$ & PBL scheme \\
\hline puff $1 \mathrm{~km}$ & 1-km grid resolution & 20 & \multirow{3}{*}{$\begin{array}{l}\text { Ground: Bulk Richardson } \\
\text { approach from Vogelezang } \\
\text { and Holtslag (1996) } \\
\text { Overwater: Gryning and } \\
\text { Batchvarova (2003) method }\end{array}$} \\
\hline puff0.3km & 0.3-km grid resolution & & \\
\hline puff0.1km & 0.1-km grid resolution & 38 & \\
\hline
\end{tabular}

Note: FLEXPART and CALPUFF default options were applied, except for the above mentioned.

Normalized mean square error (NMSE),

NMSE $=\frac{\overline{\left(\overline{C_{o}}-\overline{C_{p}}\right)^{2}}}{\bar{C}_{o} \bar{C}_{p}}$

where $C_{p}$ denotes model predictions, $C_{o}$ denotes observations, $C_{o i}$ is the $\mathrm{i}^{\text {th }}$ observed value, $C_{p i}$ is the $\mathrm{i}^{\text {th }}$ predicted value and overbar $(\bar{C})$ denotes the average over the dataset.

This quantitative assessment is complemented by the graphical comparison of ground level concentration time series from model results and observations at the two air quality sites.

Because of the limited air quality monitoring sites available in the region (Fig. 1), to intercompare the models' skills, two different approaches were applied: (a) qualitative comparison of simulated spatial plumes transport, and (b) maximum plume impact comparison (Souto et al., 2014), including:

- The simulated maximum $\mathrm{NO}_{\mathrm{x}}$ glc time series, $\mathrm{C}_{\max }$, over the simulation grid.

- The travel distance to the maximum glc time series, $X_{\max }$.

- The spatial distribution of all the maximum glc locations along the simulation period.
These intercomparison features can be useful to explain the models' results differences and, also, previous model assessments.

\section{Results}

3.1 Graphical comparison between simulated and observed time series of $N O_{x}$ concentrations

To compare the results of two Lagrangian dispersion models, FLEXPART and CALPUFF, against observations, FLEXPART (flx $1 \mathrm{~km}, \mathrm{flx} 0.3 \mathrm{~km}, \mathrm{flx} 0.1 \mathrm{~km})$, CALPUFF (puff $1 \mathrm{~km}$, puff0.3km, puff0.1km) simulations results and observed $15 \mathrm{~min} \mathrm{NO}_{\mathrm{x}}$ ground level concentration-time series at two stations are shown in Figure 7.

In all simulations both models have similar tracer arrival time at both stations, that is, $\mathrm{NO}_{\mathrm{x}}$ glc first significant values started around 0 UTC December 4 at AQS1, and around 12 UTC December 3 at AQS2; although, from the observations time series, $\mathrm{NO}_{\mathrm{x}}$ seems to arrive earlier at AQS1, around 22 UTC December 3.

Considering the observed $\mathrm{NO}_{\mathrm{x}}$ glc peaks, the largest one in AQS2 $\left(120 \mu \mathrm{g} \mathrm{m}^{-3}\right)$ is observed at 07 UTC December 4. All simulations reproduce glc 
a)

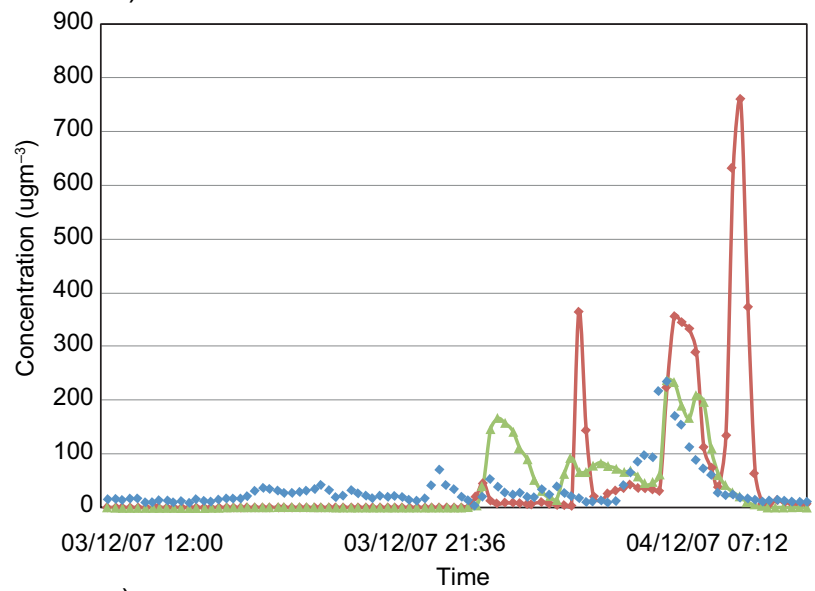

c)

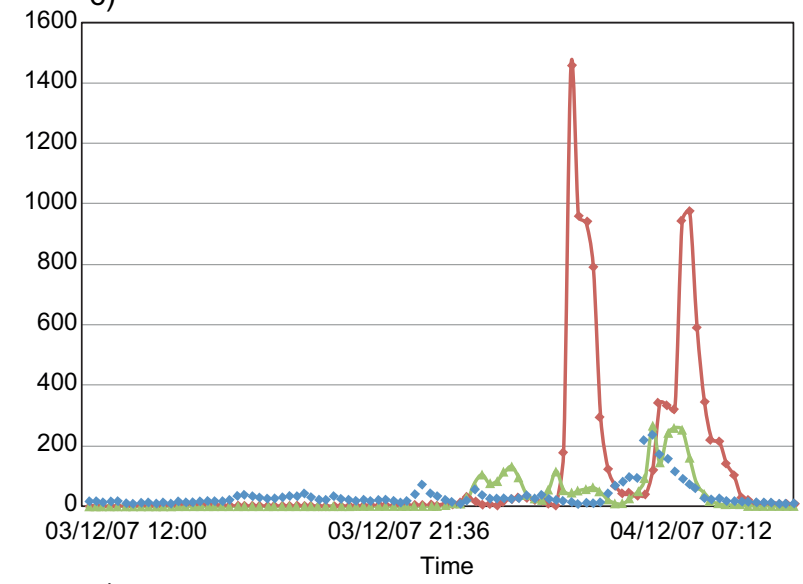

e)

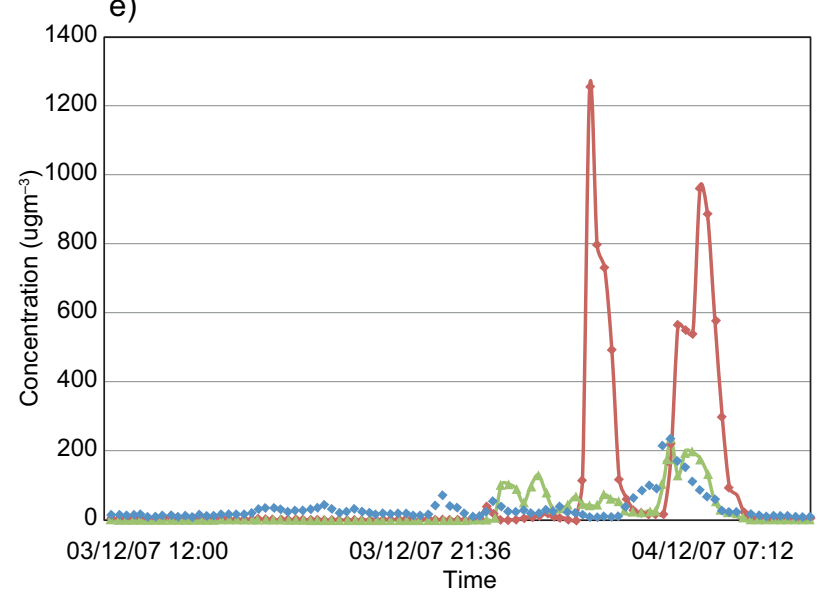

b)

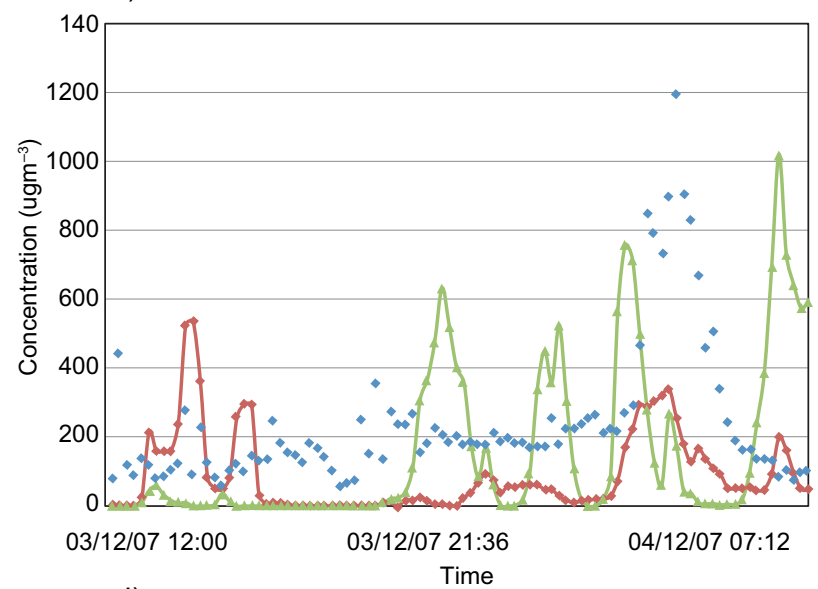

d)
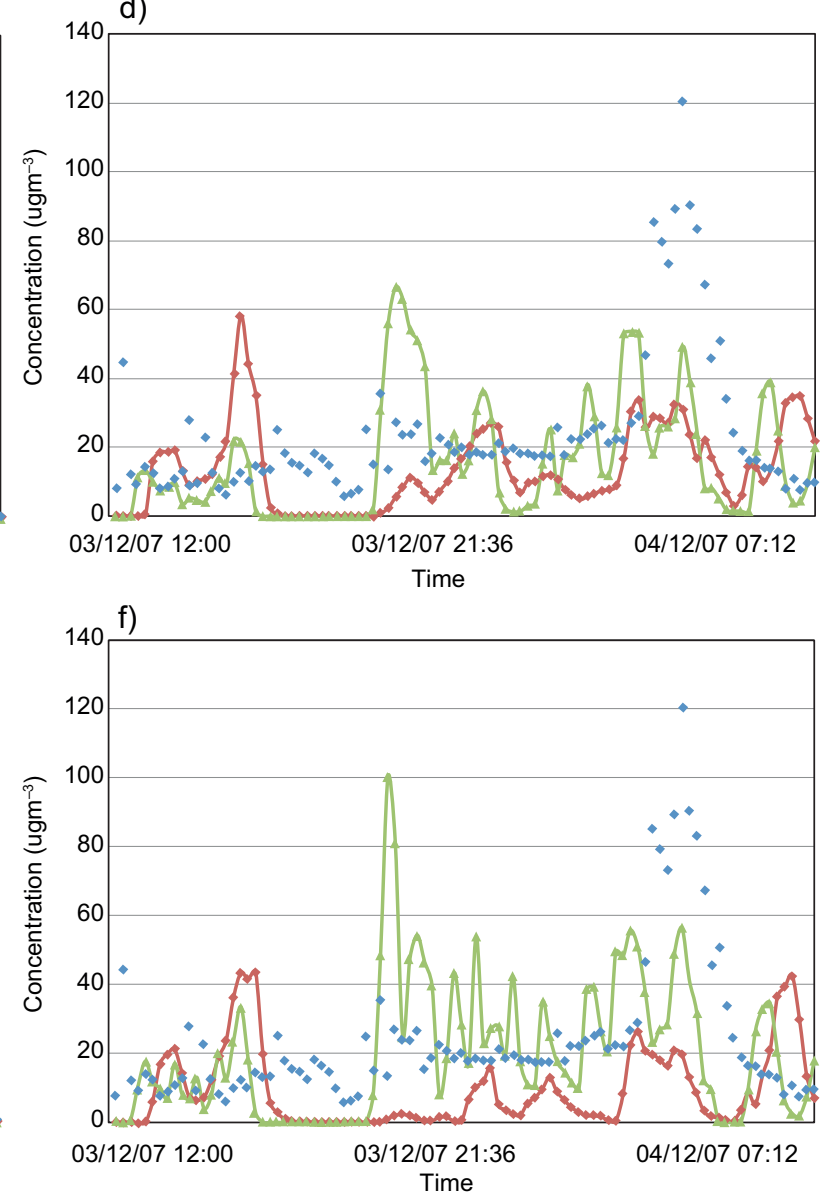

$\diamond$ Nox_mao $\rightarrow$ puff0.1km $₫$ flx $0.1 \mathrm{~km}$

Fig. 7. Comparison between time series of $15-\min \mathrm{NO}_{\mathrm{x}} \mathrm{glc}\left(\mu \mathrm{g} \mathrm{m}^{-3}\right)$ observed (blue diamonds) at AQS1 station (a, $\mathrm{c}$, e) and AQS2 station (b, d, f), and estimated with FLEXPART (green triangles line) and with CALPUFF (red diamonds line) at the same stations, along the simulation period: 16 UTC December 3 2007-16 UTC December 4 2007; using different meteorological grid resolution inputs: a, b: D4 (1 km); c, d: D5 (333 m); e, f: D6 (111 m). 
peaks around that time, but with lower values. This modeling peak underestimation occurs near primary road networks and at rush-hour traffic, so observed peaks seem linked to vehicle $\mathrm{NO}_{\mathrm{x}}$ emissions not taken into account in the models. The largest peak (below $80 \mu \mathrm{g} \mathrm{m}^{-3}$ ) is obtained in the flx $1 \mathrm{~km}$ simulation $2 \mathrm{~h}$ before the observed peak, while much lower peaks (below $60 \mu \mathrm{g} \mathrm{m}^{-3}$ ) are achieved at the observed peak time from the flx $0.3 \mathrm{~km}$ and flx $0.1 \mathrm{~km}$ simulations; also, the puff $1 \mathrm{~km}$ simulation achieves a significant peak at the same time as observed, but lower (below $40 \mu \mathrm{g} \mathrm{m}^{-3}$ ) than the other simulation peaks. In fact, both models get higher peaks several hours before the observed peaks, and these modelled peaks do not occur always at the same time for both models, even though the high sensitivity of plume transport to any errors in the wind direction provided by the WRF model is well known; also, the turbulent diffusion approaches applied for each model have a significant influence in these results.

As an example, in Figure 7a CALPUFF simulation obtains a significant glc peak at AQS1 at 4:15 UTC December 4; however, glc observations do not show any peak, in agreement with FLEXPART glc results. Otherwise, FLEXPART reproduces, in good agreement, the highest peak $\left(200 \mu \mathrm{g} \mathrm{m}^{-3}\right)$ observed in AQS1 at 5 UTC December 4, while all the CALPUFF simulations overestimate (close to $1000 \mu \mathrm{g} \mathrm{m}^{-3}$ ) that observed peak.

\subsection{Statistical evaluation results of $N O_{x}$ simulated concentrations}

From the 15-min glc time series comparison some significant differences between observed and modeled ground-level concentrations arise. Therefore, statistics provide a quantitative estimation of model errors.

Table II shows the BOOT package statistical results obtained from FLEXPART and CALPUFF simulations results against observations at AQS1 and AQS2.

From the core statistics, FB and RMSE better results were obtained using FLEXPART vs. CALPUFF, especially at AQS1, mainly because of the large CALPUFF glc peaks overestimations. Moreover, the higher meteorological resolution does not guarantee better CALPUFF results, with the worst results in puff0.3km at AQS1. However, using the FLEXPART flx $0.1 \mathrm{~km}$ simulation produced the best statistics at AQS1.
Table II. BOOT statistics $\left(\mu \mathrm{g} \mathrm{m}^{-3}\right)$ for the simulation period, using FLEXPART and CALPUFF results against observations at AQS1 and AQS2 stations.

\begin{tabular}{|c|c|c|c|c|}
\hline Simulation & NMSE & FB & FBFN & FBFP \\
\hline \multicolumn{5}{|c|}{ AQS1 Pointe-à-Pitre } \\
\hline puff1km & 8.97 & -0.38 & 0.444 & 0.824 \\
\hline flx $1 \mathrm{~km}$ & 1.79 & -0.050 & 0.459 & 0.509 \\
\hline puff0.3km & 20.17 & -1.022 & 0.254 & 1.276 \\
\hline $\mathrm{flx} 0.3 \mathrm{~km}$ & 1.89 & 0.093 & 0.540 & 0.447 \\
\hline puff0.1km & 18.37 & -0.905 & 0.331 & 1.236 \\
\hline flx $0.1 \mathrm{~km}$ & 1.60 & 0.232 & 0.605 & 0.373 \\
\hline \multicolumn{5}{|c|}{ AQS2 Baie-Mahault } \\
\hline puff1 km & 2.86 & 0.913 & 1.034 & 0.121 \\
\hline flx $1 \mathrm{~km}$ & 2.94 & 0.429 & 0.852 & 0.424 \\
\hline puff0.3km & 1.76 & 0.558 & 0.749 & 0.191 \\
\hline $\mathrm{flx} 0.3 \mathrm{~km}$ & 1.49 & 0.387 & 0.630 & 0.244 \\
\hline puff0.1km & 3.41 & 0.870 & 1.061 & 0.191 \\
\hline flx $0.1 \mathrm{~km}$ & 1.23 & 0.165 & 0.483 & 0.319 \\
\hline
\end{tabular}

NMSE: normalized mean square error; FB; fractional bias; FBFN: underpredicting component of the FB; FBFP: overpredicting component of the FB.

On the other hand, CALPUFF statistics are significantly better at AQS2 vs. AQS1, while FLEXPART statistics are similar at both stations. Also, the increase of meteorological resolution at AQS2 improves the FLEXPART results, with the minima NMSE and FB values from flx $0.1 \mathrm{~km}$ simulation. This effect is not always observed in CALPUFF results.

As expected, FBFP values show a pronounced overprediction of the observed concentrations at AQS1 in CALPUFF simulations, due to their too large modeled peaks. This FBFP overprediction of FB significantly exceeds the underprediction component FBFN. At the opposite, at AQS2 FBFN exceeds FBFP for both models' simulations, that is, both models underestimate the observed concentrations along the simulation period. This shows that models results are extremely sensitive not only to the meteorological conditions (which are quite similar at both stations) but also to the station relative location from the emission source. Therefore, in the following sections other model comparisons and assessment approaches are also applied. 

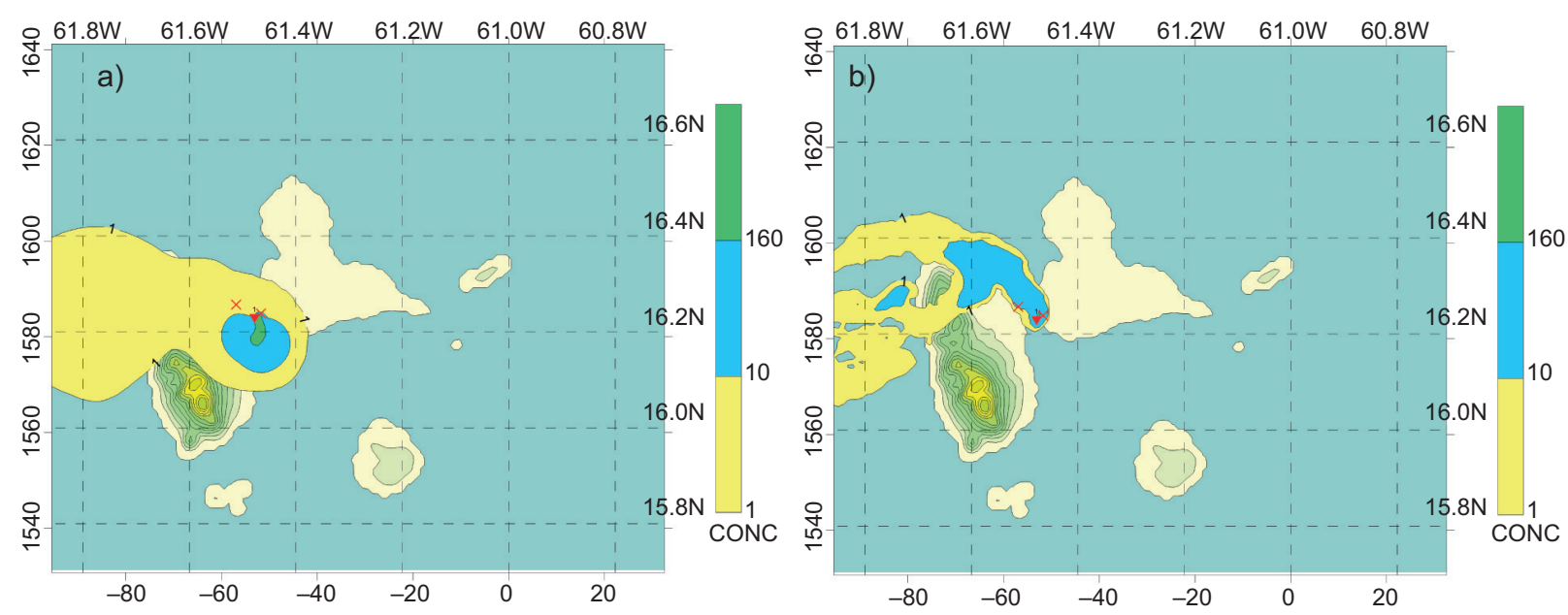

Fig. 8. Spatial distribution of $\mathrm{NO}_{\mathrm{x}}\left(\mu \mathrm{g} \mathrm{m}^{-3}\right)$ for the 1-km horizontal resolution domain (D4) at 05 UTC December 4, 2007 with source (red triangle) simulated with (a) CALPUFF and (b) FLEXPART. Also, the emission source (red triangle), the two air quality stations locations (red crosses), and topographic features are shown.

\subsection{Spatial distribution of $\mathrm{NO}_{x}$}

Considering previous statistics, the FLEXPART model performance using three different horizontal resolutions ( $1 \mathrm{~km}, 333 \mathrm{~m}$, and $111 \mathrm{~m})$ is better as the meteorological input grid resolution is finer. Therefore, as the clearest $\mathrm{NO}_{\mathrm{x}}$ glc spatial distribution, Figure 8 shows the models' glc results over the 1-km horizontal resolution domain (D4). Compact isopleths with smooth contours from CALPUFF (Fig. 8a) and fragmented isopleths with irregular contours from FLEXPART (Fig. 8b) are observed. Particularly, the influence of two topographic tops at the west of the source is apparent in the fragmented FLEXPART glc distribution (not observed in the compact CALPUFF glc distribution).

\subsection{Plume impact evaluation from simulations}

Plume impact evaluation based on the simulated maximum $\mathrm{NO}_{\mathrm{x}}$ glc, and $\mathrm{C}_{\max }$ over the simulation grid is shown in Figure 9, both for FLEXPART and CALPUFF at the three different grids resolutions. Unfortunately, it is not possible to estimate $C_{\max }$ from glc observations for model assessment, because data from only two stations are available (Souto et al., 2014).

For the $\mathrm{NO}_{\mathrm{x}}$ maximum glc, CALPUFF results are significantly higher than those from FLEXPART, and this difference increases with higher horizontal resolutions. These comparative results are consistent with the CALPUFF regulatory model condition, which guarantees glc overestimation in any condition. However, such large differences suggest that FLEXPART can be a better option for more accurate estimations in this complex domain if its systematic validation is performed.

Following the wind direction independent travel distance to the maximum concentration location $\left(\mathrm{X}_{\max }\right.$ [Fig. 10]), FLEXPART estimates higher maximum distance values than CALPUFF, while minimum values are very similar. As $\mathrm{X}_{\max }$ maximum values usually correspond to unstable conditions, with higher PBL depth, these comparative results should be a consequence of the different PBL depth schemes applied to each model in unstable conditions. In addition, higher $\mathrm{X}_{\max }$ values from FLEXPART should produce a lower estimated $\mathrm{NO}_{\mathrm{x}}$ maximum value, as the plume has more time/travel distance to be dispersed. Also, glc values at the two air quality stations should be lower using FLEXPART, because the distances from the source to these station's locations are lower than FLEXPART Xmax values, but similar to CALPUFF $\mathrm{X}_{\max }$ values. That is, these stations are located close to the CALPUFF maximum glc distance $\left(X_{\max }\right)$ but before the FLEXPART $X_{\max }$. These differences can be related to the glc overestimation observed in the CALPUFF statistical assessment. 

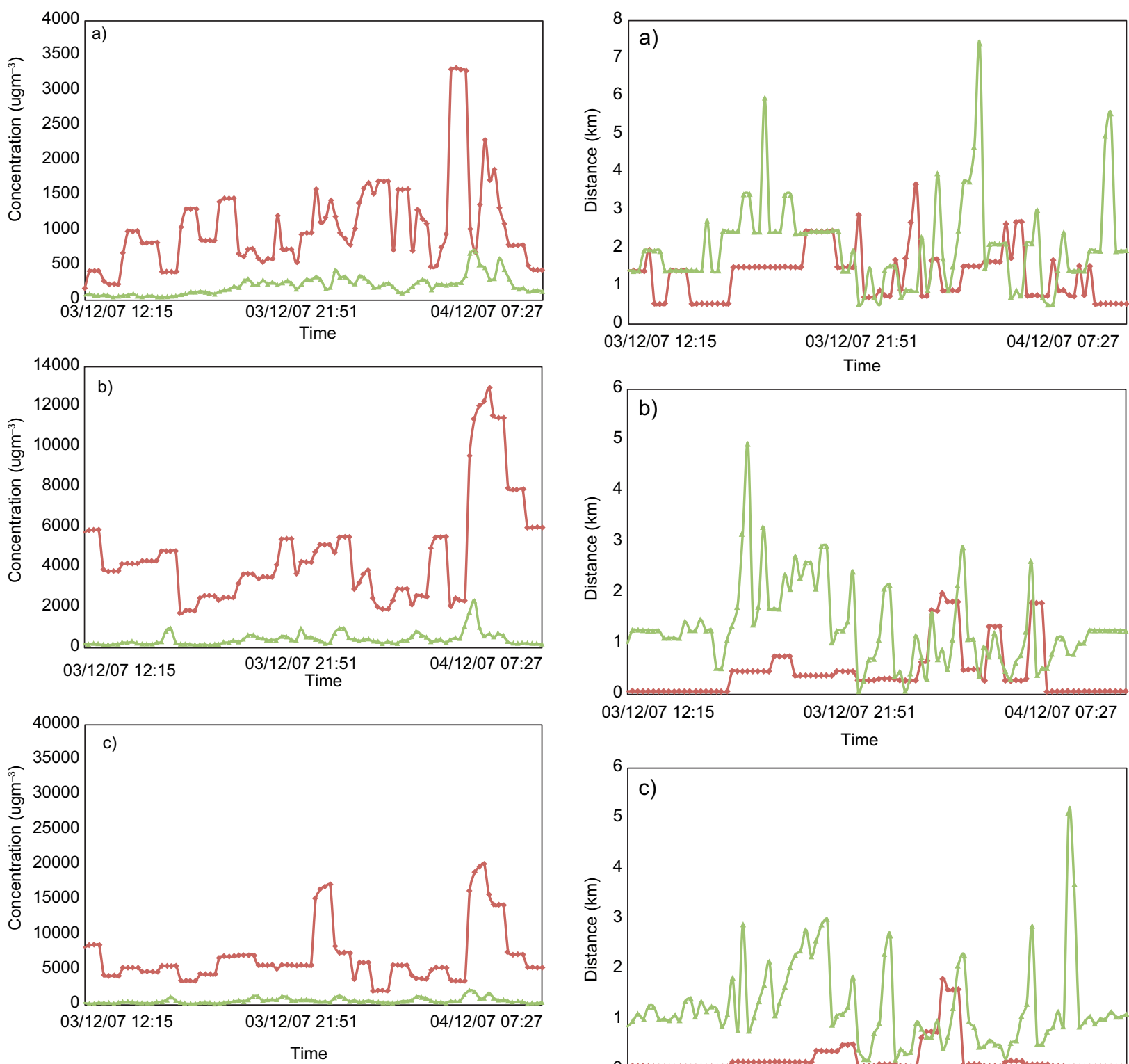

Fig. 9. Maximum $\mathrm{NO}_{\mathrm{x}}$ glc estimated with FLEXPART (green triangles) and with CALPUFF (red diamonds) for (a) 1-km; (b)-333 m, and (c) 111-m grid resolutions. The maximum simulated values for CALPUFF and FLEXPART are (a) 3321 and $716 \mu \mathrm{g} \mathrm{m}^{-3}$; (b) 12925 and $2369 \mu \mathrm{g} \mathrm{m}^{-3}$, and (c) 20133 and $2092 \mu \mathrm{g} \mathrm{m}^{-3}$, respectively.

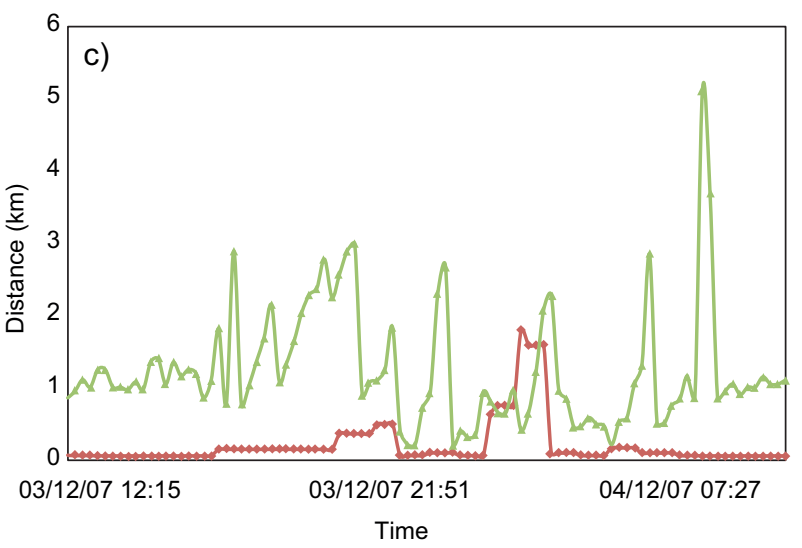

Fig. 10. Travel distance from the source to the maximum glc predicted with FLEXPART (green triangles) and with CALPUFF (red diamond). Grid resolutions: (a) $1 \mathrm{~km}$, (b) $333 \mathrm{~m}$, and (c) $111 \mathrm{~m}$.

\subsection{Spatial distribution of simulated maximum glc} locations

Besides, $\mathrm{X}_{\max }$ maximum values are higher with lower horizontal resolutions, both in FLEXPART and CALPUFF simulations; also, with differences between $\mathrm{X}_{\max }$ fluctuations over time, again depending on the resolution.

The spatial distributions of estimated maximum glc locations using the CALPUFF and FLEXPART models are shown in Figure 11. CALPUFF simulations at three different horizontal resolutions show a reduced 

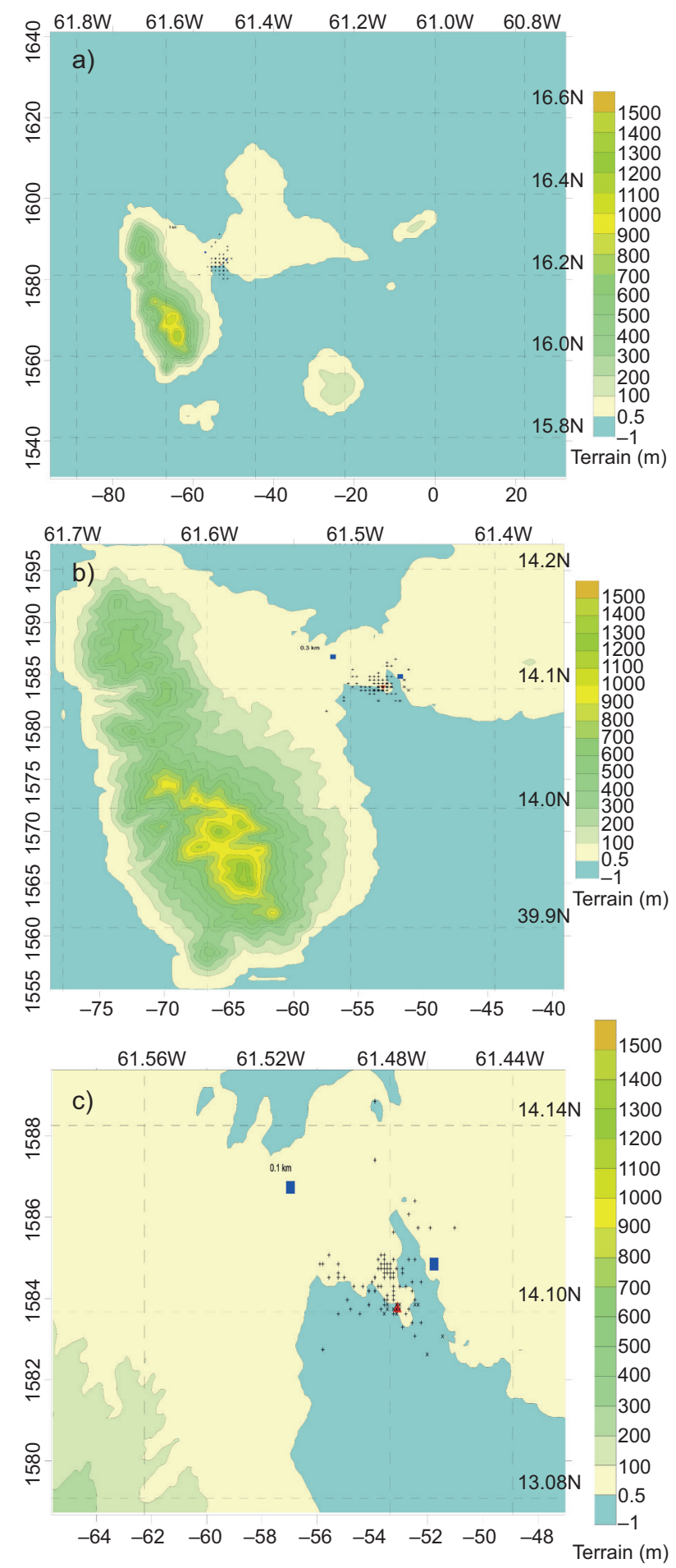

Fig. 11. Enlarged view of the maximum glc simulation locations using FLEXPART (+) and CALPUFF (x); also, the emission source (red triangle) and the two air quality stations (blue squares) locations are shown. maximum impact area, close to the emission source and the air quality stations. This feature can produce high glc estimations at station locations, which justify the overestimation observed in the CALPUFF statistical assessment.

At the opposite, FLEXPART simulations produce different maximum impact areas than CALPUFF simulations using the same horizontal resolution. Also, FLEXPART maximum impact areas are different using different resolutions, as this model seems to be sensitive to the meteorological input horizontal resolution.

\subsection{Simplified CALPUFF setup}

The statistical assessment of the default CALPUFF setup, including original schemes for some features (as the transitional plume rise and the stack tip downwash) shows worse results than FLEXPART model results. However, for a better intercomparison between both models excluding these CALPUFF original schemes (not considered in the FLEXPART model), a second simplified CALPUFF setup is evaluated.

Table III shows the statistical results from BOOT software obtained from this second simplified CALPUFF setup simulations, compared to the observations at AQS1 and AQS2 stations.

Although statistics show a poor CALPUFF performance as compared to the CALPUFF default

Table III. BOOT statistics $\left(\mu \mathrm{g} \mathrm{m}^{-3}\right)$ for the simulation period, using simplified CALPUFF simulations and observations at AQS1 and AQS2 stations.

\begin{tabular}{lcccc}
\hline Simulation & NMSE & FB & FBFN & FBFP \\
\hline \multicolumn{5}{c}{ AQS1 Pointe-à-Pitre } \\
\hline puff1 kmS & 5.50 & -0.240 & 0.448 & 0.688 \\
puff0.3kmS & 11.53 & -0.821 & 0.284 & 1.105 \\
puff0.1 kmS & 11.39 & -0.581 & 0.397 & 0.978 \\
\hline \multicolumn{5}{c}{ AQS2 Baie-Mahault } \\
\hline puff1 kmS & 5.30 & 1.317 & 1.335 & 0.018 \\
puff0.3kmS & 2.94 & 0.948 & 1.037 & 0.089 \\
puff0.1 kmS & 7.83 & 1.382 & 1.434 & 0.052 \\
\hline
\end{tabular}

NMSE: normalized mean square error; FB; fractional bias; FBFN: underpredicting component of the FB; FBFP: overpredicting component of the FB. 
setup simulations assessment (Table II), a significant improvement is observed. Therefore, original CALPUFF schemes for downwash of the plume rise and stack tip are not recommended in this case study. Otherwise, CALPUFF performance is still far from the FLEXPART statistics, as significant differences in model's results remains.

\section{Conclusions}

Currently, two Lagrangian atmospheric dispersion approaches (particle and puff models) are usually applied to estimate passive pollutants dispersion over a complex terrain environment. In this work, a singular simulation domain, the Guadeloupe archipelago, was selected to test the FLEXPART Lagrangian particle model and the CALPUFF Lagrangian puff model. This domain includes several islands with complex terrain and strong sea influence in the Caribbean Region. Also, weak winds conditions were selected, as they produce the highest air pollution levels observed in this region. $\mathrm{NO}_{\mathrm{x}}$ emissions from a single power plant located on the main island were considered as a passive tracer.

Both Lagrangian models were coupled to the same WRF meteorological results at three different high-resolution grids (up to $111 \mathrm{~m}$ ) to test their relative accuracy by comparison to 15-min ground level concentration observations at two air quality stations close to the emission source. During the testing period, the statistical model assessment showed that FLEXPART achieves significantly better agreement with glc observations than CALPUFF.

About the models' intercomparison, the spatial distribution of $\mathrm{NO}_{\mathrm{x}}$ shows homogenous isopleths with smooth contours for CALPUFF, while fragmented isopleths with irregular contours are observed with FLEXPART, showing the effect of the complex topography over the $\mathrm{NO}_{\mathrm{x}}$ plume. Considering the estimated maximum $\mathrm{NO}_{\mathrm{x}}$ glc, CALPUFF results are much higher than FLEXPART, and CALPUFF results increase with the meteorological input resolution. Travel distance to the maximum glc is usually longer with FLEXPART than with CALPUFF, and further away from the air quality stations. This feature is in agreement with the higher CALPUFF maximum glc results and, also, its glc overestimation observed in this model assessment. Also, maximum glc locations from CALPUFF results are concentrated in a small area close to the air quality stations, while the corresponding FLEXPART locations are further away from the emission source and they extend over larger areas.

\section{Acknowledgments}

The authors wish to thank Bart Brashers, who helped with the MMIF bug fixes to preprocess our WRF simulations and for providing important ideas to finish this work. The authors also wish to thank professor María Heidi Trujillo Fernández who helped with the review of the English manuscript.

\section{References}

Anderson BA, Brode RW. 2010. Evaluation of four Lagrangian models against the Cross-Appalachian and European Tracer experiments. In: Air pollution modeling and its application XX (Douw G. Steyn S, Rao T, Eds.). IOS Press/Springer Science, Amsterdam, Dordrecht, 87-93.

Anderson JR, Hardy EE, Roach JT, Witmer RE. 1976. A land use and land cover classification system for use with remote sensor data. Technical report 964. United States Geological Survey. https://doi.org/10.3133/ pp964

Arnold D, Maurer C, Wotawa G, Draxler R, Saito K, Seibert P. 2015. Influence of the meteorological input on the atmospheric transport modelling with FLEXPART of radionuclides from the Fukushima Daiichi nuclear accident. Journal of Environmental Radioactivity 139:212-225. https://doi.org/10.1016/j. jenvrad.2014.02.013

Bauer TJ, Gibbs RL. 1998. Software user's manual for the Chemical/Biological Agent Vapor, Liquid, Gibbs and Solid Tracking (VLSTRACK) computer model, version 3.0. NSWCDD/TR-98/62. Systems Research and Technology Department, Dahlgren Division, Naval Surface Warfare Center, Dahlgren, VA, 170 pp.

Bei N, G Li, Zavala M, Barrera H, Torres R, Grutter M, Gutiérrez W, García M, Ruiz-Suárez LG, Ortínez A, Gutiérrez Y, Alvarado C, I Flores, Molina LT. 2013. Meteorological overview and plume transport patterns during Cal-Mex 2010. Atmospheric Environment 70: 477-489. https://doi.org/10.1016/j. atmosenv.2012.01.065 
Brashers B, Emery C. 2019. The Mesoscale Model Interface (MMIF) program version 3.4.1. Available at: https:/gaftp.epa.gov/Air/aqmg/SCRAM/models/ related/mmif/MMIFv3.4.1_Users_Manual.pdf

Causley MC. 1992. User's guide for the Urban Airshed Model. Vol. IV: Emissions preprocessor system version 2.0. EPA-450/4-90-007DR. United States Environmental Protection Agency.

Cécé R, Bernard D, Brioude J, Zahibo N. 2014. Numerical simulations of island-induced circulations and windward katabatic flow over the Guadeloupe archipelago. Monthly Weather Review 142: 850-867. https:// doi.org/10.1175/mwr-d-13-00119.1

Cécé R, Bernard D, Brioude J, Zahibo N. 2016. Microscale anthropogenic pollution modelling in a small tropical island during weak trade winds: Lagrangian particle dispersion simulations using real nested LES meteorological fields. Atmospheric Environment 139: 98-112. https://doi.org/10.1016/j.atmosenv.2016.05.028

Chang JC, Franzese P, Chayantrakom K, Hanna SR. 2003. Evaluations of CALPUFF, HPAC, and VLSTRACK with two mesoscale field datasets. Journal of Applied Meteorology 42: 453-466. https://doi.org/10.1175/15 20-0450(2003)042<0453: eochav $>2.0$. co;2

Chang JC, SR Hanna. 2005. Technical descriptions and user's guide for the Boot Statistical Model Evaluation software package, version 2.0. Available at: https:// www.harmo.org/Kit/Download/BOOT_UG.pdf

Cheng S, An X, Zhou L, Tans PP, Jacobson A. 2017. Atmospheric $\mathrm{CO}_{2}$ at Waliguan station in China: Transport climatology, temporal patterns and sourcesink region representativeness. Atmospheric Environment 159: 107-116. https://doi.org/10.1016/j. atmosenv.2017.03.055

Cohen J, Cook R, Bailey CR, Carr E. 2005. Relationship between motor vehicle emissions of hazardous pollutants, roadway proximity, and ambient concentrations in Portland, Oregon. Environmental Modelling \& Software 20: 7-12. https://doi.org/10.1016/j.envsoft.2004.04.002

Deardorff JW. 1970. Convective velocity and temperature scales for the unstable planetary boundary layer and for Rayleigh convection. Journal of the Atmospheric Sciences 27: 1211-1213. https://doi. org/10.1175/1520-0469(1970)027<1211: cvatsf $>2.0$. co;2

Djambazov G, Pericleous K. 2015. Modelled atmospheric contribution to nitrogen eutrophication in the English Channel and the southern North Sea. Atmospheric
Environment 102: 191-199. https://doi.org/10.1016/j. atmosenv.2014.11.071

Draxler RR, Hess GD. 1998. An overview of the HYSPLIT_4 modelling system for trajectories. Australian Meteorological Magazine 47: 295-308.

Dresser AL, Huizer RD. 2011. CALPUFF and AERMOD model validation study in the near field: Martins Creek revisited. Journal of the Air \& Waste Management Association 61: 647-659. https://doi.org/10.3155/10473289.61.6.647

DTRA. 1999. HPAC hazard prediction and assessment capability, version 3.2. Defense Threat Reduction Agency, Alexandria, VA, 406 pp.

Dudhia J. 1989. Numerical study of convection observed during the winter monsoon experiment using a mesoscale two-dimensional model. Journal of the Atmospheric Sciences 46: 3077-3107. https://doi. org/10.1175/1520-0469(1989)046<3077:nsocod $>2.0$. co;2

EEA. 2007. CLC2006 technical guidelines. Technical report 17/2007. European Environment Agency, Copenhagen, $67 \mathrm{pp}$.

Fallah-Shorshani M, Shekarrizfard M, Hatzopoulou M. 2017. Evaluation of regional and local atmospheric dispersion models for the analysis of traffic-related air pollution in urban areas. Atmospheric Environment 167: 270-282. https://doi.org/10.1016/j. atmosenv.2017.01.006

Fishwick S, Scorgie Y. 2011. Performance of CALPUFF in predicting time-resolved particulate matter concentrations from a large-scale surface mining operation. In: CASANZ Conference Proceedings, July 30-August 2, Auckland, New Zealand, 1-5.

Ghannam K, el-Fadel M. 2013. Emissions characterization and regulatory compliance at an industrial complex: an integrated MM5/CALPUFF approach. Atmospheric Environment 69: 156-169. https://doi.org/10.1016/j. atmosenv.2012.12.022

Gryning SE, Batchvarova E. 2003. Marine boundary-layer height estimated from NWP Model Output. International Journal of Environment and Pollution 20: 147153. https://doi.org/10.1504/IJEP.2003.004264

Gulia S, Kumar A, Khare M. 2015. Performance evaluation of CALPUFF and AERMOD dispersion models for air quality assessment of an industrial complex. Journal of Scientific \& Industrial Research 74: 302-307.

Halse AK, Eckhardt S, Schlabach M, Stohl A, Breivik K. 2013. Forecasting long-range atmospheric transport 
episodes of polychlorinated biphenyls using FLEXPART. Atmospheric Environment 71: 335-339. https:// doi.org/10.1016/j.atmosenv.2013.02.022

Hanna SR. 1982. Applications in air pollution modeling. In: Atmospheric turbulence and air pollution modelling (Nieuwstadt FT, van Dop H., Eds.). D. Reidel, Dordrecht, Holland, 379 pp.

Hernández-Garcés A, Souto JA, Rodríguez A, Saavedra S, Casares JJ. 2015a. Validation of CALMET/CALPUFF models simulations around a large power plant stack. Física de la Tierra 27: 35-55. https://doi.org/10.5209/ rev_FITE.2015.v27.51192

Hernández A, Jáuregui U, Souto JA, Casares JJ, Saavedra S, Guzmán F, Torres A. 2015b. Estado actual de los modelos de dispersión atmosférica y sus aplicaciones. UCE Ciencia. Revista de postgrado 3: 1-17.

Hernández-Garcés A, Jáuregui-Haza U, González JA, Casares-Long JJ, Saavedra-Vázquez S, Guzmán-Martínez F, Torres-Valle A. 2016. Aplicaciones del modelo lagrangiano de dispersión atmosférica CALPUFF. Ciencias de la Tierra y el Espacio 17: 32-44.

Holnicki P, Kałuszko A, Trapp W. 2016. An urban scale application and validation of the CALPUFF model. Atmospheric Pollution Research 7: 393-402. https:// doi.org/10.1016/j.apr.2015.10.016

Holtslag AAM, Nieuwstadt FTM. 1986. Scaling the atmospheric boundary layer. Boundary-Layer Meteorology 36: 201-209. https://doi.org/10.1007/BF00117468

Hong S-Y, Noh Y, Dudhia J. 2006. A new vertical diffusion package with an explicit treatment of entrainment processes. Monthly Weather Review 134: 2318-2341. https://doi.org/10.1175/mwr3199.1

ICF Consulting. 2002. User's guide to the Regional Modeling System for Aerosols and Deposition (REMSAD).

Levy J, Wilson AM, Evans JS, Spengler JD. 2003. Estimation of primary and secondary particulate matter intake fractions for power plants in Georgia. Environmental Science \& Technology 37: 5528-5536. https://doi. org/10.1021/es0344841.s001

Ludwig FL, Salvador R, Bornstein R. 1989. An adaptive volume plume model. Atmospheric Environment 23: 127-138. https://doi.org/10.1016/00046981(89)90105-4

Miao Y, Liu S, Zheng Y, Wang S, Chen B, Zheng H, Zhao J. 2015. Numerical study of the effects of local atmospheric circulations on a pollution event over Beijing-Tianjin-Hebei, China. Journal of Environ- mental Sciences 30: 9-20. https://doi.org/10.1016/j. jes.2014.08.025

Mlawer EJ, Taubman SJ, Brown PD, Iacono MJ, Clough SA. 1997. Radiative transfer for inhomogeneous atmosphere: RRTM, a validated correlated-k model for the longwave. Journal of Geophysical Research 102: 16663-16682. https://doi.org/10.1029/97jd00237

Monin AS, Obukhov AM. 1954. Basic laws of turbulent mixing in the ground layer of the atmosphere. Transactions of the Geophysical Institute, Academy of Sciences, USSR 151: 163-187.

O’Neill SM, Lamb BK, Chen J, Napelenok S, Allwine EJ, Stock D, McManus JB, Shorter JH, Kolb CE. 2001. Correlating an upwind source-footprint with urban emissions data using the MM5/MCIP/CALPUFF modeling system. In: 10th International Emission Inventory Conference "One Atmosphere, One Inventory, Many Challenges", May 1 - 3, 1-10.

Pielke RA. 1984. Mesoscale meteorological modeling. Academic Press, London.

Pineda N, Jorba O, Jorge J, Baldasano JM. 2004. Using NOAA AVHRR and SPOT VGT data to estimate surface parameters: application to a mesoscale meteorological model. International Journal of Remote Sensing 25: 129-143. https://doi. org $/ 10.1080 / 0143116031000115201$

Pivato A, Barausse A, Zecchinato F, Palmeri L, Raga R, Lavagnolo MC, Cossu R. 2015. An integrated model-based approach to the risk assessment of pesticide drift from vineyards. Atmospheric Environment 111: 136-150. https://doi.org/10.1016/j. atmosenv.2015.04.005

Protonotariou A, Bossioli E, Athanasopoulou E, Dandou A, Tombrou M, Assimakopopoulos V, Flocas HA, Chelmis C. 2004. Validation and inter-comparison of CALPUFF regulatory model to Eulerian models and measurements. An application over the greater Athens area, Greece. In: Proceedings of the $9^{\text {th }}$ International Conference on Harmonization within Atmospheric Dispersion Modelling for Regulatory Purposes, Garmisch-Partenkirchen, Germany, June, 131-135.

Ramsdell JV, Simonen CA, Burk KW. 1994. Regional Atmospheric Transport Code for Hanford Emission Tracking (RATCHET). PNWD-2224-HEDR. Pacific Northwest Laboratories, Richland, Washington.

Rood AS. 2014. Performance evaluation of AERMOD, CALPUFF, and legacy air dispersion models using 
the winter validation tracer study dataset. Atmospheric Environment 89: 707-720. https://doi.org/10.1016/j. atmosenv.2014.02.054

Ryall DB, Maryon RH. 1997. Validation of the UK Met Office's NAME model against the ETEX dataset. In: ETEX Symposium on Long-Range Atmospheric Transport. Model Verification and Emergency Response (Nodop K, Ed.). European Commission, EUR 17 346, 151-154. https://doi.org/10.1016/s13522310(98)00177-0

Saltbones J, Foss A, Bartnicki J. 1996. Severe nuclear accident programme (SNAP). A real time model for accidental releases. In: The Fifth International Atmospheric Sciences and Applications to Air Quality Conference, University of Washington, Seattle, June 18-20. https://doi.org/10.1007/978-1-4615-5841-5_50

Scire JS, Strimaitis DG, Yamartino RJ. 2000. A user's guide for the CALPUFF dispersion model. Earth Tech, Concord MA, USA.

Scire JS, Strimaitis DG, Wu ZX. 2013. Evaluation of AERMOD, CALPUFF and CAMx with the Kincaid tracer dataset. Guideline on Air Quality Models: The Path Forward. Raleigh, North Carolina, 19-21 March. Seinfeld JH, Pandis SN. 2012. Atmospheric chemistry and physics: From air pollution to climate change. John Wiley \& Sons.

Skamarock WC, Klemp JB, Dudhia J, Gill DO, Barker DM, Duda MG, Huang X-Y, Wang W, Powers JG. 2008. A description of the Advanced Research WRF version 3. Technical report NCAR/TN-475+STR. University Corporation for Atmospheric Research. http://dx.doi.org/10.5065/D68S4MVH

Souto JA, Pérez-Muñuzuri V, de Castro M, Souto MJ, Casares JJ, Lucas T. 1998. Forecasting and diagnostic analysis of plume transport around a power plant. Journal of Applied Meteorology 37: 1068-1083. https:// doi.org/10.1175/1520-0450(1998)037<1068:fadaop$>2.0 . \operatorname{co} ; 2$

Souto JA, de Castro M, Casares JJ, Souto MJ, Pérez-Muñuzuri V, Bermúdez JL. 2000. Testing of an adaptive puff model for regulatory purposes around As Pontes power plant. International Journal of Environment and Pollution 14: 198-207. https://doi. org/10.1504/IJEP.2000.000541

Souto MJ, Souto JA, Pérez-Muñuzuri V, Casares JJ, Bermúdez JL. 2001. A comparison of operational Lagrangian particle and adaptive puff models for plume dispersion forecasting. Atmospheric Environ- ment 35: 2349-2360. https://doi.org/10.1016/s13522310(00)00537-9

Souto JA, Hermida M, Casares JJ, Bermúdez JL. 2009. SAGA: A decision support system for air pollution management around a coal-fired power plant. International Journal of Environment and Pollution 38: 444-461. https://doi.org/10.1504/IJEP.2009.027275

Souto JA, Moral C, Rodríguez A, Saavedra S, Casares JJ, Hernández-Garcés A. 2014. Simulation of plume dispersion using different stack configurations and meteorological inputs. International Journal of Environment and Pollution 55: 139-147. https://doi. org/10.1504/IJEP.2014.065917

Srinivas CV, Prasad KH, Naidu CV, Baskaran R, Venkatraman B. 2016. Sensitivity analysis of atmospheric dispersion simulations by FLEXPART to the WRF-simulated meteorological predictions in a coastal environment. Pure and Applied Geophysics 173: 675700. https://doi.org/10.1007/s00024-015-1104-z

Stohl A, Hittenberger M, Wotawa G. 1998. Validation of the Lagrangian particle dispersion model FLEXPART against large-scale tracer experiment data. Atmospheric Environment 32: 4245-4264. https://doi.org/10.1016/ s1352-2310(98)00184-8

Stull RB. 1988. An introduction to boundary layer meteorology. Kluwer Academic Publisher, Springer, Dordrecht, The Netherlands.

Tanaka SI. 2012. Accident at the Fukushima Dai-ichi nuclear power stations of TEPCO_outline \& lessons learned. Proceedings of the Japan Academy, Series B 88: 471-484. https://doi.org/10.2183/pjab.88.471

Tartakovsky D, Broday DM, Stern E. 2013. Evaluation of AERMOD and CALPUFF for predicting ambient concentrations of total suspended particulate matter (TSP) emissions from a quarry in complex terrain. Environmental Pollution 179: 138-145. https://doi. org/10.1016/j.envpol.2013.04.023

Tartakovsky D, Stern E, Broday DM. 2016. Comparison of dry deposition estimates of AERMOD and CALPUFF from area sources in flat terrain. Atmospheric Environment 142: 430-432. https://doi.org/10.1016/j. atmosenv.2016.08.035

Tesche TW, McNally DE, Morris RE, Emery C. 2001. Evaluation of CAMx and models-3/CMAQ over the Lower Lake Michigan region with inputs from the RAMS3c and MM5 models. Prepared for the Coordinating Research Council by Alpine Geophysics, Fort Wright, KY, USA. US-EPA. 1992. User's instructions. User's guide for the in- 
dustrial source complex (ISC) dispersion models, vol. 1. EPA 450/4 92-008a, U.S. Environmental Protection Agency, Research Triangle Park, North Carolina, USA. VDI. 2000. VDI 3945. Environmental meteorology - Atmospheric dispersion models - Particle model. Engl. VDI/DIN-Kommission Reinhaltung der Luft (KRdL) - Normenausschuss.

Vogelezang D, Holtslag A. 1996. Evaluation and model impacts of alternative boundary-layer height formulations. Boundary-Layer Meteorolorogy 81: 245-269. https://doi.org/10.1007/bf02430331

Wei P, Cheng S, Li J, Su F. 2011. Impact of boundary-layer anticyclonic weather system on regional air quality. Atmospheric Environment 45: 2453-2463. https://doi. org/10.1016/j.atmosenv.2011.01.045
Yang JE. 2014. Fukushima Dai-Ichi accident: Lessons learned and future actions from the risk perspectives. Nuclear Engineering and Technology 46: 27-38. https://doi.org/10.5516/NET.03.2014.702

Yau KH, Macdonald RW. The 2010 inter-comparison of the AUSTAL2000 and CALPUFF dispersion models against the Kincaid data set. International Journal of Environment and Pollution 40: 267-279. https://doi. org/10.1504/ijep.2010.030898

Zannetti P. 2013. Air pollution modeling: Theories, computational methods and available software. Springer Science \& Business Media. 